\title{
Planting method, nitrogen fertilization and inoculation for diazotrophic bacteria for Cantaloupe melon plants
}

\section{Método de siembra, fertilización con nitrógeno e inoculación con bacterias diazotróficas en melón Cantaloupe}
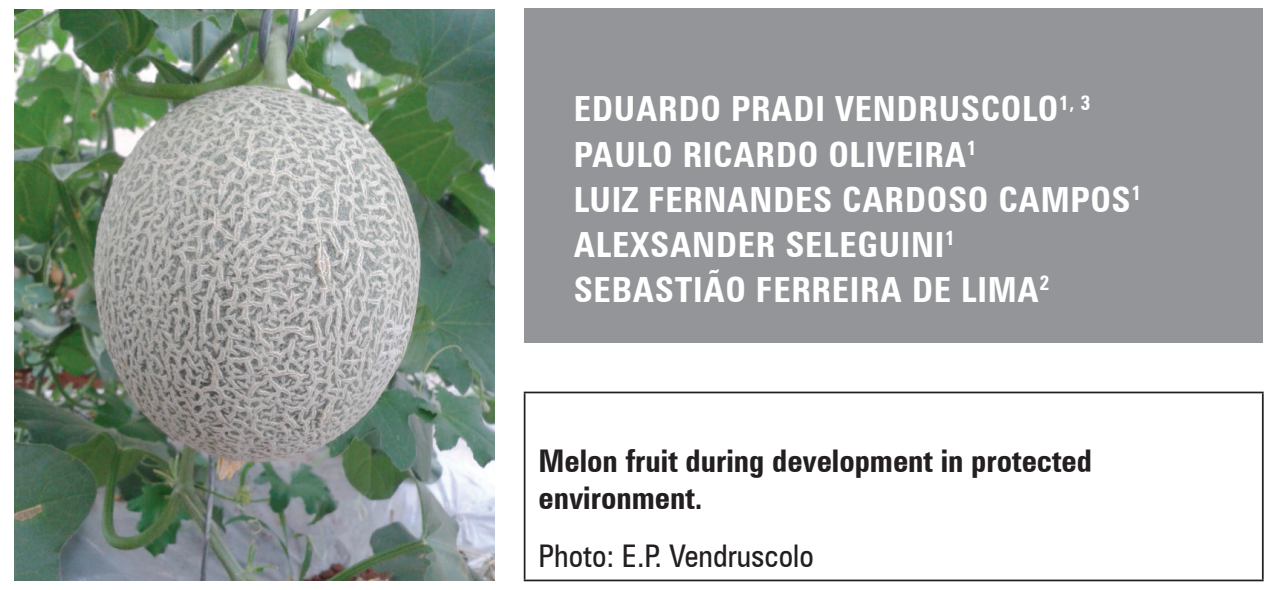

\begin{abstract}
The objective of this study was to evaluate the effects on plant development, productivity and fruit quality from combinations of planting methods, nitrogen fertilizer applications and inoculation with Azospirillum brasilense in Cantaloupe melons cultivated in a protected environment. A randomized blocks design was adopted with a $2 \times 2 \times 2$ factorial scheme with five replications. The treatments consisted of combinations of planting methods (pre-established seedlings or direct field sowing), inoculation with A. brasilense (with or without) and nitrogen fertilization (with and without). During the vegetative phase, the height, stem diameter, number and length of plant internodes and relative chlorophyll content were evaluated. Fifty-five days after planting, the leaf nitrogen content, leaf area and dry mass were measured. At harvest, the number of days between planting and harvesting was calculated, and the fresh weight, circumference, length, bark and pulp thickness and fruit productivity were evaluated. It was verified that $A$. brasilense did not affect any of the evaluated characteristics. On the other hand, direct field seed sowing decreased the production time and provided good plant development. However, the size and productivity of the fruits were higher when preestablished seedlings were used, with or without inoculation with $A$. brasilense, fertilized with nitrogen. It was concluded that the combinations of the different sowing methods, nitrogen fertilization and inoculation with $A$. brasilense affected the development and characteristics of the Cantaloupe melon plants and fruits.
\end{abstract}

Additional key words: Cucumis melo L. var. reticulatus Naud; muskmelon;
Azospirillum brasilense; sustainable management; soil acidification.

1 Universidade Federal de Goiás, Escola de Agronomia, Setor de Horticultura, Goiás (Brazil). ORCID Vendruscolo, E.P.: 0000-0002-3404-8534; ORCID Oliveira, P.R.: 0000-0001-6094-743X; ORCID Campos, L.F.C.: 0000-0001-5171-5194; ORCID Seleguini, A.: 0000-0002-5762-9278

2 Universidade Federal de Mato Grosso do Sul, Campus de Chapadão do Sul, Mato Grosso do Sul (Brazil). ORCID Lima, S.F.: 0000-0001-5693-912X

3 Corresponding author. agrovendruscolo@gmail.com 


\section{RESUMEN}

El objetivo de este trabajo fue evaluar los efectos sobre el crecimiento de las plantas, la productividad y la calidad de la fruta estudiando la combinación entre el sistema de siembra, fertilización con nitrógeno e inoculación con Azospirillum brasilense en melón cantaloupe cultivado en ambiente protegido. Se utilizó un diseño de bloques completos al azar en esquema factorial de $2 \times 2 \times 2$, con cinco repeticiones. Los tratamientos correspondieron a: sistemas de siembra (trasplante de plántulas o siembra directa), inoculación con Azospirillum brasilense (con o sin) y fertilización con nitrógeno (con y sin). Durante la fase vegetativa, se evaluaron la altura, diámetro del cuello, número y longitud de entrenudos, así como el contenido relativo de clorofila total. También se obtuvo a los 55 días de la siembra el contenido de nitrógeno foliar, el área foliar y la masa seca. En la cosecha, se calculó el número de días entre la siembra y la cosecha, junto con la masa fresca, circunferencia, longitud, grosor de la corteza y pulpa, y el rendimiento de la fruta. Se verificó que la inoculación con A. brasiliense no alteró ninguna de las características evaluadas. Por otro lado, la siembra directa en el campo disminuyó el tiempo de producción y proporcionó un mejor desarrollo de las plantas. Sin embargo, el trasplante de plántulas y la fertilización con nitrógeno, incrementó el tamaño y la productividad de las frutas de melón Cantaloupe. Se concluyó que la combinación entre diferentes métodos de siembra, fertilización nitrogenada e inoculación con A. brasilense afecta el desarrollo y las características de las plantas y frutos de melón Cantaloupe.

Palabras clave adicionales: Cucumis melo L. var. reticulatus Naud.; melones; Azospirillum brasilense; manejo sostenible; acidificación del suelo.

Received for publication: 06-01-2019 Accepted for publication: 29-03-2019

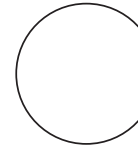

In twenty years, melon (Cucumis melo L.) production has increased by 14.5 million tons, between 1994 and 2014, and China is the top producer, with more than half of the total fruit production (FAO, 2017). In Latin America, about 1.0 million tons of melons are produced every year. Brazil provides approximately $50 \%$ of this amount, with a cultivation area of 22.000 .000 (FAO, 2017).

In the majority of cases, particularly in yellow melons, which are the most produced domestically, the cultivation of melons in Brazil is carried out in the open field (Souza et al., 2014). However, protected environments have grown because they facilitate characteristics for management that protects against biotic and abiotic stresses (Chang et al., 2013) and produce fruits that have a higher physicochemical quality (Coelho et al., 2003; Vargas et al., 2008), mainly with fruits with higher value added, such as Cantaloupe melons (Cucumis melo L. reticulatus Naud.), which can result in high profitability for producers (Vendruscolo et al., 2017).

Cantaloupe melon plants responds positively to nitrogen fertilization with significant increases in fruit yield when high doses of nitrogen, varying from 160 to $413 \mathrm{~kg} \mathrm{ha}^{-1}$, are applied in crops cultivated under protected environment (Coelho et al., 2003; Fontes et al., 2004; Queiroga et al., 2011; Silva et al., 2014). Excessive applications of nitrogen fertilizers, however, can result in a high release of $\mathrm{H}^{+}$ions in the soil solution, causing acidification (Lu et al., 2014). Thus, alternatives that decrease the use of nitrogen fertilization and/or increase its efficiency should be the target of research, aiming at sustainability in the productive system.

The use of diazotrophic bacteria is widely discussed and has a high application potential for crops of economic interest, mainly cereals (Hungria, 2011; Araújo et al., 2014; Andrade et al., 2016; Bulegon et al., 2016). However, for fruit species, few results have been provided, mainly because of the absence of studies dedicated to this area. These bacteria have been observed in the production of tomato and onion seedlings. Pulido et al. (2003) observed positive developmental effects when inoculation of $A$. brasilense was used in seed pretreatment. In tomato production, Guevara et al. (2013) observed a savings of about $30 \%$ in the use of nitrogen fertilizers when the plants were submitted to inoculation with Azospirillum brasilense. 
The objective of this study was to evaluate the effects on the vegetative and productive characteristics of combinations of planting systems, nitrogen fertilization and inoculation with Azospirillum brasilense in Cantaloupe melon plants grown in a protected environment.

\section{MATERIAL AND METHODS}

This study was conducted in Goiânia, Goiás state, Brazil. This municipality is located in the central region of the State, $16^{\circ} 40^{\prime} \mathrm{S}$ and $49^{\circ} 15^{\prime} \mathrm{W}$, with an altitude of $750 \mathrm{~m}$. According to Cardoso et al. (2014), the climate is Aw according to the classification of Köppen-Geiger, characterized by a tropical climate with a rainy season from October to April and a period with monthly precipitations below $100 \mathrm{~mm}$ between May and September. Mean monthly temperatures range from $20.8^{\circ} \mathrm{C}$ in June and July to $25.3^{\circ} \mathrm{C}$ in October (Cardoso et al., 2014). During the experiment, the climatic records of the air temperature and humidity inside the protected environment (Fig. 1), were obtained with a digital datalogger (AK172, Akso, São Leopoldo, RS, Brazil).

The protected environment used for the cultivation was an arch model, $21 \mathrm{~m}$ long, $7 \mathrm{~m}$ wide, and 2.10 $\mathrm{ft}$ high, with a $4 \mathrm{~m}$ ridge, covered with transparent plastic and the sides closed with a white anti-aphidic screen. The front and rear openings, equivalent to arches, provided greater ventilation, avoiding excessive heat inside the growing environment.
Santos et al. (2013) stated that the soil present in the experimental area is Latosolo Vermelho. According to the analysis established by Embrapa (Donagemma et al., 2011), this kind of soil has the following characteristics: $\mathrm{Ca}^{2+}=5.70 \mathrm{cmol}_{\mathrm{c}} \mathrm{dm}^{-3}, \mathrm{Mg}^{2+}=3.00 \mathrm{cmol}_{c}$ $\mathrm{dm}^{-3}, \mathrm{~K}^{+}=96.00 \mathrm{mg} \mathrm{dm}^{-3}, \mathrm{P}$ (Mehlich I) $=170.00 \mathrm{mg}$ $\mathrm{dm}^{-3}$, organic material $=23.00 \mathrm{~g} \mathrm{~kg}^{-1}, \mathrm{Al}^{3+}=0.0 \mathrm{cmol}_{\mathrm{c}}$ $\mathrm{dm}^{-3}, \mathrm{H}+\mathrm{Al}=2.40 \mathrm{cmol}_{\mathrm{c}} \mathrm{dm}^{-3}$ and $\mathrm{pH}\left(\mathrm{CaCl}_{2}\right)=5.50$. The granulometric analysis of the soil presented $48.00 \mathrm{~g} \mathrm{~kg}^{-1}$ of clay in the layer $0-0.20 \mathrm{~m}$, following the analysis proposed by Silva (2009).

The experiment was designed in randomized blocks, in a $2 \times 2 \times 2$ factorial scheme with five replications. The treatments consisted of combinations of planting systems (pre-established seedlings or direct field sowing), inoculation with Azospirillum brasilense (with or without) and the application of $120 \mathrm{~kg} \mathrm{ha}^{-1}$ of nitrogen in the form of urea (with and without). Each plot had five plants, and the three central plants formed the useful plot.

For the formation of seedlings, on September $7^{\text {th }}$, 2016, seeds of Cantaloupe melon, cv. Trinity, were sown in expanded polystyrene trays containing 128 cells, filled commercial turfous substrate (Germinar, Bioflora, Prata, MG, Brazil). Twenty-three days after being sown, the seedlings were transplanted to previously prepared beds, fertilized with $4 \mathrm{~L} \mathrm{~m}^{-1}$ of tanned bovine manure ( $88.00 \mathrm{~g} \mathrm{~kg}^{-1}$ de M.O.; $\mathrm{pH}=7.20$; 82.00 $\mathrm{g} \mathrm{kg}^{-1} \mathrm{~N} ; 3.10 \mathrm{~g} \mathrm{~kg}^{-1} \mathrm{P}$ (Mehlich); $20.80 \mathrm{~g} \mathrm{~kg}^{-1} \mathrm{~K} ; 3.00$ $\mathrm{g} \mathrm{kg}^{-1} \mathrm{Ca} ; 3.00 \mathrm{~g} \mathrm{~kg}^{-1} \mathrm{Mg} ; 50.00 \mathrm{~g} \mathrm{~kg}^{-1} \mathrm{C} ; 0.19 \mathrm{mg} \mathrm{kg}^{-1}$ Fe; $36.00 \mathrm{mg} \mathrm{kg}^{-1} \mathrm{Mn} ; 26.50 \mathrm{mg} \mathrm{kg}^{-1} \mathrm{Zn} ; 0.00 \mathrm{mg} \mathrm{kg}^{-1}$ $\mathrm{Cu} ; 0.60 \mathrm{C} / \mathrm{N}$ ratio) and $15 \mathrm{~g} \mathrm{~m}^{-1}$ of Yoorin Master.

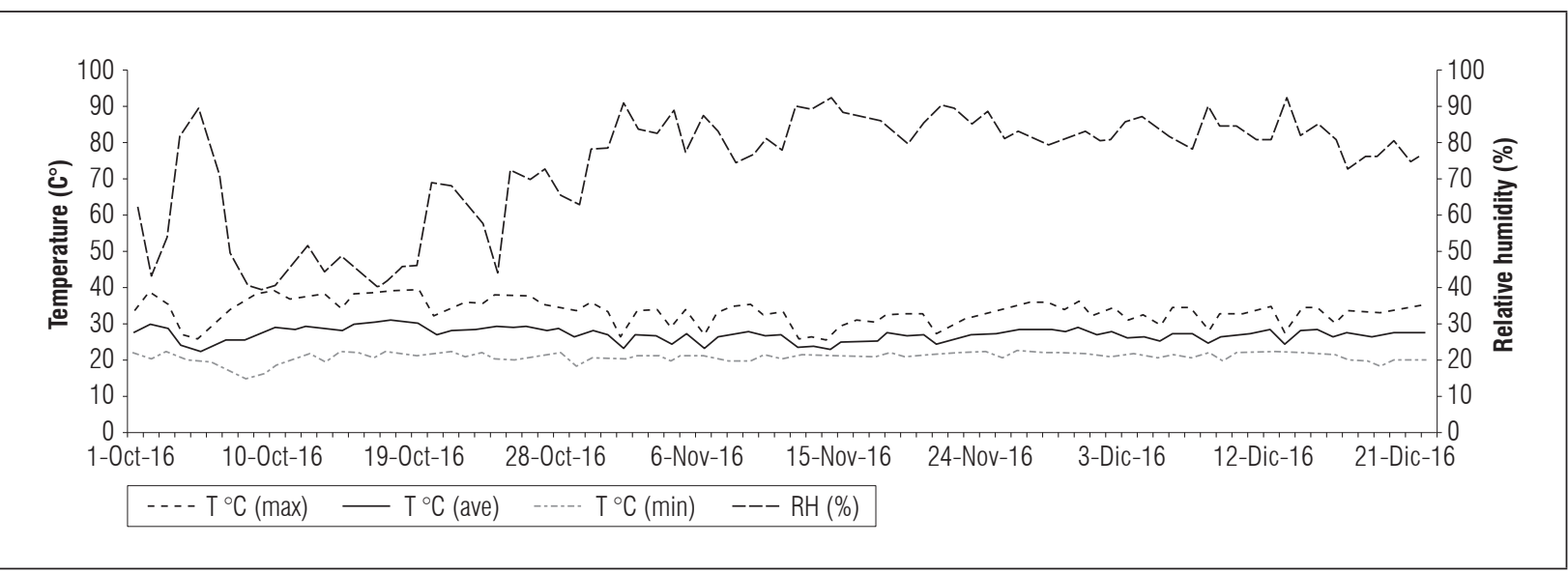

Figure 1. Summary of climatic conditions of relative air humidity and maximum, average and minimum temperature during the study. Goiânia-G0, 2016. 
Meanwhile, the sowing was also carried out directly in the beds, according to the treatment. For the planting, a space of $0.45 \times 0.8 \mathrm{~m}$ was used between plants and between rows (beds), respectively (Vendruscolo et al., 2018). The nitrogen applications were performed manually. The equivalent of a $40 \mathrm{~kg} \mathrm{ha}^{-1}$ dose of urea was diluted in $500 \mathrm{~mL}$ of water, and the solution was applied throughout the plot, at 15, 30 and $45 \mathrm{~d}$ after planting. A. brasilense was applied in a dose of $10 \mathrm{~mL} \mathrm{~L}^{-1}$ of the commercial product (NITRO1000 Gramineae) as soon as the first nitrogen fertilization was carried out.

The plants were irrigated with drip tapes spaced 20 $\mathrm{cm}$, vertically conducted using plastic wires as tutors. For the control of fungal diseases, whitefly and $D i$ aphania spp., fungicide based on Metiram and Piraclostroblina (55\% and 5\% a.i.) and insecticides based on Thiamethoxam (25\% a.i.) and Lambda cyhalothrin $(25 \%$ a.i.) were applied at 10, 15 and $64 \mathrm{~d}$ after installation of the experiment.

The evaluation of the plants' biometric characteristics was carried out 15,30 and $45 \mathrm{~d}$ after sowing, when the values of height, diameter at soil level, and number and length of the internodes were measured. Also, the relative content of total chlorophyll was measured with a digital chlorophyllometer (CFL1030; Falker, Porto Alegre-RS, Brazil) on a medium-plant leaf. Within $55 \mathrm{~d}$, the relative contents of chlorophyll, leaf area and dry mass of the fourth leaf, taken from the plant apex, were also evaluated.

The harvest started $72 \mathrm{~d}$ after planting and continued for a period of $10 \mathrm{~d}$. Within this period, the number of days between planting and harvesting was evaluated and the fresh fruit weight characteristics were obtained with a digital scale (W15, Welmy, Sta. Bárbara d'Oeste-SP, Brazil). The fruit circumference was measured with a metric tape, and the fruit length and bark and pulp thickness were obtained with a digital caliper (Metrotools, São Paulo, SP, Brazil). The productivity was estimated for an area of 1 ha, the soluble solids content ( ${ }^{\circ}$ Brix) was read with a manual refractometer RTA-50 (Instrutherm, São Paulo, SP, Brazil), the titratable acidity was obtained with titration with a $\mathrm{NaOH}$ solution $(1 \mathrm{M})$, and the ratio between the latter two variables provided the Ratio (SS/TA).

The data were submitted to analysis of variance, and the means were compared with the Tukey test at 5\% probability, using statistical software Sisvar (Ferreira, 2014).

\section{RESULTS AND DISCUSSION}

It was verified that inoculation with Azospirillum brasilense did not affect the vegetative plant development in isolation. However, the planting system and the nitrogen cover fertilization influenced plant height, stem diameter, number of nodes, length of internodes and relative levels of total chlorophyll (Tab. 1).

During the entire period of evaluation of the vegetative characteristics, a higher height and number of nodes were observed in the plants grown from preestablished seedlings (Tab. 1). This result was due to uniform seedling development, maintaining constant superiority, because they were transplanted with an initial height of approximately $15 \mathrm{~cm}$ and with two to three nodes in the main branch.

For the stem diameter and the length of the internode, the superiority of the plants obtained with direct sowing in the beds was observed starting from the second evaluation (Tab. 1). This result may be related to the restriction of space and nutrients to which the pre-established seedlings were submitted during the initial development in the trays, resulting in a less thick stem and shortening of the initial internodes.

There was also superiority in the plants from preestablished seedlings for the relative contents of total chlorophyll in the first and second evaluation (Tab. 1). In the development of the plants obtained from direct sowing, however, this variable was equal in the third evaluation. Thus, larger leaf quantities, as well as the increase in their size, contributed to selfshading in the medium portion of the melon plants. According to Gonçalves et al. (2012), higher shading rates increase the relative chlorophyll content in the leaf limbus.

The nitrogen application did not interfere with the vegetative characteristics of the melon plants (Tab. 1). These results are related to favorable soil chemical characteristics, as well as to the addition of tanned bovine manure, which served as a source of nitrogen and other nutrients during the establishment and development of the melon plants.

Fifty-five days after planting, no difference was observed in the leaf nitrogen contents of the fourth leaf from the plant apex. However, throughout the evaluation of the leaf area and dry mass, it was observed that direct seeding favored leaf development (Tab. 2). 
Table 1. Plant height, stem diameter, number of nodes, internode length and total relative chlorophyll content (RCC) in melon plants cultivated in different production systems. Goiânia-G0, 2016.

\begin{tabular}{|c|c|c|c|c|c|}
\hline \multirow[b]{2}{*}{ Planting system } & \multicolumn{4}{|c|}{ Plant development } & \multirow{2}{*}{$\begin{array}{c}\text { RCC } \\
\text { (SPAD) }\end{array}$} \\
\hline & $\begin{array}{l}\text { Height } \\
\text { (cm) }\end{array}$ & $\begin{array}{c}\text { Diameter } \\
(\mathrm{mm})\end{array}$ & $\begin{array}{c}\mathrm{N}^{0} \text { of nodes } \\
-\end{array}$ & $\begin{array}{l}\text { Internode } \\
(\mathrm{cm})\end{array}$ & \\
\hline \multicolumn{6}{|c|}{15 days after planting } \\
\hline Seed & 10.09 b & $5.26 \mathrm{a}$ & $4.06 \mathrm{~b}$ & $2.49 \mathrm{~b}$ & $40.86 b$ \\
\hline Seedling & 44.63 a & $5.56 \mathrm{a}$ & 10.17 a & $4.36 \mathrm{a}$ & $43.31 \mathrm{a}$ \\
\hline \multicolumn{6}{|l|}{ Nitrogen } \\
\hline With & $27.07 \mathrm{a}$ & $5.42 \mathrm{a}$ & $7.33 \mathrm{a}$ & $3.41 \mathrm{a}$ & $42.49 \mathrm{a}$ \\
\hline Without & $27.65 \mathrm{a}$ & $5.40 \mathrm{a}$ & $6.90 \mathrm{~b}$ & $3.44 \mathrm{a}$ & $41.69 \mathrm{a}$ \\
\hline CV\% & 32.49 & 14.78 & 14.97 & 24.13 & 6.65 \\
\hline \multicolumn{6}{|c|}{30 days after planting } \\
\hline Seed & $120.67 \mathrm{~b}$ & 8.59 a & $15.42 b$ & $7.81 \mathrm{a}$ & $48.02 \mathrm{~b}$ \\
\hline Seedling & $158.73 \mathrm{a}$ & $7.68 \mathrm{~b}$ & 23.33 a & $6.79 b$ & $53.21 \mathrm{a}$ \\
\hline \multicolumn{6}{|l|}{ Nitrogen } \\
\hline With & $137.83 \mathrm{a}$ & 8.07 a & 19.31 a & $7.21 \mathrm{a}$ & $50.52 \mathrm{a}$ \\
\hline Without & $141.56 \mathrm{a}$ & 8.19 a & 19.44 a & $7.40 \mathrm{a}$ & $50.71 \mathrm{a}$ \\
\hline CV\% & 14.05 & 10.90 & 10.82 & 10.30 & 6.97 \\
\hline \multicolumn{6}{|c|}{45 days after planting } \\
\hline Seed & $215.00 \mathrm{~b}$ & $9.56 \mathrm{a}$ & $27.52 \mathrm{~b}$ & $7.82 \mathrm{a}$ & $49.01 \mathrm{a}$ \\
\hline Seedling & $233.00 \mathrm{a}$ & $8.45 b$ & 33.33 a & $7.01 \mathrm{~b}$ & $50.01 \mathrm{a}$ \\
\hline \multicolumn{6}{|l|}{ Nitrogen } \\
\hline With & $229.00 \mathrm{a}$ & $9.11 \mathrm{a}$ & 30.72 a & $7.52 \mathrm{a}$ & $49.86 \mathrm{a}$ \\
\hline Without & $219.00 \mathrm{~b}$ & $8.91 \mathrm{a}$ & $30.13 \mathrm{a}$ & $7.31 \mathrm{a}$ & $49.16 \mathrm{a}$ \\
\hline CV\% & 10.71 & 13.45 & 8.97 & 9.13 & 8.36 \\
\hline
\end{tabular}

Means followed by same letters in the columns did not differ according to the Tukey test $(P \leq 0.05)$; CV: coefficient of variation.

Table 2. Leaf area and dry mass at $\mathbf{5 5} \mathrm{d}$ after planting, on melon plants cultivated in different production systems. Goiânia-G0, 2016.

\begin{tabular}{|c|c|c|}
\hline Planting system & $\begin{array}{c}\text { Leaf area } \\
\left(\mathrm{cm}^{2}\right)\end{array}$ & $\begin{array}{c}\text { Leaf dry mass } \\
(\mathrm{g})\end{array}$ \\
\hline Seed & $87.41 \mathrm{a}$ & $0.33 \mathrm{a}$ \\
\hline Seedling & $78.00 \mathrm{~b}$ & $0.29 \mathrm{~b}$ \\
\hline \multicolumn{3}{|c|}{ Nitrogen } \\
\hline With & $85.90 \mathrm{a}$ & $0.32 \mathrm{a}$ \\
\hline Without & $79.50 \mathrm{~b}$ & $0.30 \mathrm{a}$ \\
\hline CV\% & 17.92 & 21.57 \\
\hline
\end{tabular}

Means followed by same letters in the columns did not differ according to the Tukey test $(P \leq 0.05)$; $\mathrm{CV}$ : coefficient of variation.

The results can be attributed to the higher nutrient translocation capacity favored by the larger stem diameters obtained for these plants, including nitrogen, which also had a positive influence on leaf development. This result agrees with Brunes et al. (2015) who inferred that secondary stem growth represents a relevant factor to the accumulation of dry matter in the aerial part of plants once the organ obtains the function of transporting essential elements, such as water, nutrients and mineral salts.

For the transverse circumference, as well as the longitudinal circumference and productivity, an interaction between the three factors (Tab. 3) was observed. In general, it was verified that the nitrogen fertilization applied to the plants coming from pre-established seedlings, not inoculated with $A$. brasilense, resulted in a higher fruit development and, consequently, in an increased productivity (Tab. 3). 


\section{Table 3. Transversal circumference, longitudinal circumference and productivity of the Cantaloupe melon fruits according to the different production systems. Goiânia, 2016.}

\begin{tabular}{|c|c|c|c|c|}
\hline \multicolumn{5}{|c|}{ Transverse circumference (cm) } \\
\hline \multirow{4}{*}{ Planting system } & \multicolumn{4}{|c|}{ Azospirillum brasilense } \\
\hline & \multicolumn{2}{|c|}{ With } & \multicolumn{2}{|c|}{ Without } \\
\hline & \multicolumn{4}{|c|}{ Nitrogen } \\
\hline & With & Without & With & Without \\
\hline Seed & $42.21 \mathrm{aA} 1$ & $41.55 \mathrm{bA} 1$ & $41.63 \mathrm{bA} 1$ & 41.19 aA1 \\
\hline Seedling & $42.71 \mathrm{aA} 1$ & $43.76 \mathrm{aA} 1$ & $43.85 \mathrm{aA} 1$ & $39.07 \mathrm{aB} 2$ \\
\hline CV\% & \multicolumn{4}{|c|}{7.08} \\
\hline \multicolumn{5}{|c|}{ Longitudinal circumference $(\mathrm{cm})$} \\
\hline \multirow{4}{*}{ Planting system } & \multicolumn{4}{|c|}{ Azospirillum brasilense } \\
\hline & \multicolumn{2}{|c|}{ With } & \multicolumn{2}{|c|}{ Without } \\
\hline & \multicolumn{4}{|c|}{ Nitrogen } \\
\hline & With & Without & With & Without \\
\hline Seed & $45.22 \mathrm{aA} 1$ & $43.09 \mathrm{bA} 1$ & $43.35 \mathrm{bA} 1$ & $43.64 \mathrm{aA} 1$ \\
\hline Seedling & $45.03 \mathrm{aA} 1$ & 46.33 aA1 & $46.84 \mathrm{aA} 1$ & $42.15 \mathrm{aB} 2$ \\
\hline CV\% & \multicolumn{4}{|c|}{7.94} \\
\hline \multicolumn{5}{|c|}{ Produtivity (Mg ha-1) } \\
\hline \multirow{4}{*}{ Planting system } & \multicolumn{4}{|c|}{ Azospirillum brasilense } \\
\hline & \multicolumn{2}{|c|}{ With } & \multicolumn{2}{|c|}{ Without } \\
\hline & \multicolumn{4}{|c|}{ Nitrogen } \\
\hline & With & Without & With & Without \\
\hline Seed & 36.79 aA1 & $31.19 \mathrm{bA} 1$ & $33.13 \mathrm{bA} 1$ & $33.49 \mathrm{aA} 1$ \\
\hline Seedling & $38.08 \mathrm{aA} 1$ & 40.36 aA1 & $41.21 \mathrm{aA} 1$ & 30.06 bB2 \\
\hline CV\% & \multicolumn{4}{|c|}{24.41} \\
\hline
\end{tabular}

Means followed by the same lowercase letter in the columns, upper case in the rows for the factor $A$. brasilense, and the same numbers in the lines for the nitrogen factor do not differ according to the Tukey test at 5\% probability; CV: coefficient of variation.

Under the experiment conditions, the productivity of the Cantaloupe melons fertilized with nitrogen reached a mean of $37.30 \mathrm{Mg} \mathrm{ha}^{-1}, 10.4 \%$ higher than the yield of $33.78 \mathrm{Mg} \mathrm{ha}^{-1}$ obtained in the plots without nitrogen fertilization. Similar results were observed in a study by Silva et al. (2014) who verified that nitrogen fertilizations up to the $160 \mathrm{~kg} \mathrm{ha}^{-1}$ dose provided increases in fruit yield and quality. Results described by Fontes et al. (2004) and Queiroga et al. (2011) also showed positive responses of the development of Cantaloupe melon fruits up to doses of 373 and $413 \mathrm{~kg} \mathrm{ha}^{-1}$ of $\mathrm{N}$, respectively.

It was verified that the inoculation with the bacteria favored the development and the productivity of fruits in the plants obtained from direct field sowing when combined with the nitrogen cover fertilization and in the plants obtained from pre-established seedlings when nitrogen cover fertilization was not carried out (Tab. 3). The application of $A$. brasilense may not substitute nitrogen fertilization, but some studies have suggested that the inoculation of plants with these bacteria may promote better utilization of available soil nitrogen (Saubidet et al., 2002), improving the development of morphophysiological characteristics (Taiz et al., 2017).

Despite the limited information regarding inoculation with A. brasilense in horticultural species, studies have demonstrated its effectiveness. Working with tomato, Guevara et al. (2013) observed that plant inoculation with $A$. brasilense allowed a savings of about $30 \%$ in the use of nitrogen fertilizers. Inoculation with $A$. brasilense as a seed treatment was also 
effective for the formation of tomato and onion seedlings, favoring development through the improvement of nutritional status (Pulido et al., 2003).

It was also verified that, when inoculation with A. brasilense or nitrogen cover fertilization was not carried out, the plants obtained from direct sowing provides greater fruit development and productivity. The larger diameter of the stem, observed in the plants obtained from direct sowing, along with the non-restriction of the space for the initial development of the roots, may have contributed to a greater exploitation of the soil, culminating in greater efficiency in the absorption and translocation of nutrients and others substances (Nibau et al., 2008; Brunes et al., 2015; Borcioni et al., 2016).

The treatments used in the present study did not influence the average production time, in days, between the planting and the harvest, with a mean of $76 \mathrm{~d}$. However, this result shows a higher precocity of production in plants obtained from direct sowing since the formation of seedlings in the trays lasted exactly $23 \mathrm{~d}$.

Thus, the development of new studies that focus on the increase of the productive capacity of plants obtained from direct sowing is recommended. The improvement of this technique will contribute to greater gains for the rural producer. Moreover, it will eliminate the costs associated with labor, structures and inputs in seedling production.

\section{CONCLUSIONS}

Different combinations of the sowing methods, nitrogen fertilization and inoculation with $A$. brasilense affected the development and characteristics of the Cantaloupe melon plants and fruits.

\section{ACKNOWLEDGMENTS}

The authors thank the Coordination of Improvement of Higher Level Personnel - CAPES for granting the scholarship to the first author.

Conflict of interests: this manuscript was prepared and reviewed with the participation of all authors, who declare that there exists no conflict of interest that puts at risk the validity of the presented results.

\section{BIBLIOGRAPHIC REFERENCES}

Andrade, A.T., A.B.T. Condé, R.L. Costa, A.W.V. Pomela, A.L. Soares, F.A.D. Martins, W.T. Lima, and C.B. Oliveira. 2016. Produtividade de milho em função da redução do nitrogênio e da utilização de Azospirillum brasilense. Rev. Bras. Milho Sorgo 15, 229-239. Doi: 10.18512/1980-6477/rbms.v15n2p229-239

Araújo, É.O., A.C.T. Vitorino, F.M. Mercante, D.P. Nunes, and S.D.P.Q. Scalon. 2014. Qualidade de sementes de milho em resposta à adubação nitrogenada e à inoculação com bactérias diazotróficas. Agrária 9, 159-165. Doi: 10.5039/agraria.v9i2a2695

Borcioni, E., Á.F. Mógor, and F. Pinto. 2016. Influence of the application of fulvic acid on seedling root growth and yield in lettuce. Rev. Cienc. Agron. 47, 509-515. Doi: 10.5935/1806-6690.20160061

Brunes, R.R., A.D.C. Lucio, M. Toebe, D.V. Schwertner, and F. Haesbaert. 2015. Relationships among traits in bell pepper derived from seeds with different levels of physiological quality. Caatinga 28, 108-118. Doi: 10.1590/1983-21252015v28n313rc

Bulegon, L.G., V.F. Guimarães, V.A. Egewarth, M.G. Santos, A.L. Heling, S.D. Ferreira, A.P.G.S. Wengrat, and A.G. Battistus. 2016. Crescimento e trocas gasosas no período vegetativo da soja inoculada com bactérias diazotróficas. Nativa 4, 277-286. Doi: 10.14583/23187670.v04n05a03

Cardoso, M.R.D., F.F.N. Marcuzzo, and J.R. Barros. 2014. Classificação climática de KÖPPEN-GEIGER para o estado de Goiás e o Distrito Federal. Acta Geogr. 8(16), 40-55.

Chang, J., X. Wu, Y. Wang, L.A. Meyerson, B. Gu, Y. Min, H. Xue, C. Peng, and Ge, Y. 2013. Does growing vegetables in plastic greenhouses enhance regional ecosystem services beyond the food supply? Front Ecol. Environ. 11(1), 43-49. Doi: 10.1890/100223

Coelho, E.L., P.C.R. Fontes, F.L. Finger, and A.A. Cardoso. 2003. Qualidade do fruto de melão rendilhado em função de doses de nitrogênio. Bragantia 62, 173-178. Doi: 10.1590/S0006-87052003000200001

Donagemma, G.K., V.D.B. Campos, S.B. Calderano, W.G. Teixeira, and J.H.M. Viana. 2011. Manual de métodos de análise de solo. $2^{\text {nd }}$ ed. Empresa Brasileira de Pesquisa Agropecuária, Rio de Janeiro, Brazil.

FAO. 2017. FAOSTAT. Food and agriculture data. In: http:// www.fao.org/faostat/en/\#data/QC; consulted: November, 2019.

Ferreira, D.F.2014. Sisvar: a guide for its Bootstrap procedures in multiple comparisons. Cienc. Agrotecnol. 38(2), 109-112. Doi: 10.1590/S1413-70542014000200001

Fontes, P.C.R., E.L. Coelho, A.A. Cardoso, and F.L. Finger. 2004. Produtividade do melão rendilhado em ambiente 
protegido e no campo, em função de doses de nitrogênio. Biosci. J. 20, 15-20.

Gonçalves, J.F.C., C.E.M. Silva, G.C. Justino, and A.R. Nina Junior. 2012. Efeito do ambiente de luz no crescimento de plantas jovens de mogno (Swietenia macrophylla King). Sci. For. 40, 337-344.

Guevara, Y.V., Y. Ruisánchez, A. Hernández, and S.J. Rodríguez. 2013. Evaluación del biofertilizante Nitrofix en el cultivo de tomate. Solanum lycopersicum L. sobre 51 un suelo ferralítico rojo típico. Rev. ICIDCA 47, 3-7.

Hungria, M. 2011. Inoculação com Azospirillum brasilense: inovação em rendimento a baixo custo. Embrapa Soja, Londrina, Brazil.

Lu, X., Q. Mao, F.S. Gilliam, Y. Luo, and J. Mo. 2014. Nitrogen deposition contributes to soil acidification in tropical ecosystems. Glob Change Biol. 20, 3790-3801. Doi: $10.1111 /$ gcb.12665

Nibau, C., D.J. Gibbs, and J.C. Coates. 2008. Branching out in new directions: the control of root architecture by lateral root formation. New Phytol. 179, 595-614. Doi: 10.1111/j.1469-8137.2008.02472.x

Pulido, L.E., N. Medina, and A. Cabrera A. 2003. La biofertilización con rizobacterias y hongos micorrízicos arbusculares en la producción de posturas de tomate Lycopersicon esculentum Mill. y cebolla Allium cepa L. II. Colonización radical y estado nutricional. Cultivos Tropicales 24, 5-13.

Queiroga, F.M., S.Â.D. Costa, F.H.F. Pereira, P.B. Maracajá, and A.L. Sousa Filho. 2011. Efeito de doses de nitrogênio na produção e qualidade de frutos de melão gália. Rev. Verde 6, 96-100.

Santos, H.G., P.K.T. Jacomine, L.H.C. Anjos, V.A. Oliveira, J.F. Lumbreiras, M.R. Coelho, J.A. Almeida, T.J.F. Cunha, and J.B. Oliveira. 2013. Sistema brasileiro de classificação de solos. $3^{\text {th }}$ ed. Empresa Brasileira de Pesquisa Agropecuária, Brasilia.
Saubidet, M.I., N. Fatta, and A.J. Barneix. 2002. The effect of inoculation with Azospirillum brasilense on growth and nitrogen utilization by wheat plants. Plant Soil 245, 215-222. Doi: 10.1023/A:1020469603941

Silva, F.C. 2009. Manual de análises químicas de solos, plantas e fertilizantes. $2^{\text {nd }}$ ed. Empresa Brasileira de Pesquisa Agropecuária, Brasilia.

Silva, M.D.C., T. Silva, E.M. Bonfim-Silva, and N. Lorraine. 2014. Características produtivas e qualitativas de melão rendilhado adubado com nitrogênio e potássio. Rev. Bras. Eng. Agr. Amb. 18(6), 581-587. Doi: 10.1590/S1415-43662014000600003

Souza, M.H.C., M.V.T. Silva, O.C. Melo, F.L. Oliveira, and A.F. Neto. 2014. Avaliação Pós-Colheita do Melão Amarelo submetido Danos Mecânicos. Rev. Verde 9, 195-200.

Taiz, L., E. Zeiger, I.M. Moller, and A. Murphy. 2017. Plant physiology and development. $6^{\text {th }}$ ed. Sinauer Associates, Sunderland, MA.

Vargas, P.F., R. Castoldi, H.C.D.O. Charlo, and L.T. Braz. 2008. Qualidade de melão rendilhado. Cucumis melo L. em função do sistema de cultivo. Cienc. Agrotec. 32, 137-142. Doi: 10.1590/S1413-70542008000100020

Vendruscolo, E.P., A. Seleguini, L.F.C. Campos, A.H.A. Rodrigues, and S.F. de Lima. 2018. Desenvolvimento e produção de melão Cantaloupe em função do espaçamento e ambientes de cultivo no Cerrado brasileiro. Rev. Colomb. Cienc. Hortic. 12(2), 397-404. Doi: 10.17584/rcch.2018v12i2.7794

Vendruscolo, E.P., L.F.C. Campos, A. Seleguini, A.P.B. Martins, and S.F. Lima. 2017. Economic viability of muskmelon cultivation in different planting spacing in Brazil central region. Rev. Fac. Nac. Agron. Medellín 70, 8319-8325. Doi: 10.15446/rfna.v70n3.62656 